\title{
RECAPITULATION OF TRANSCRIPTOMIC CHARACTERISTICS OF PRIMARY BREAST TUMOURS IN PATIENT-DERIVED 3D CULTURES IN VITRO
}

\author{
Dina Nitiša, Nityanand Jain, Arvīds Irmejs, Valdis Pirsko, and Inese Čakstina ${ }^{\#}$ \\ Institute of Oncology, Rīga Stradinš University, 13 Pilsoṇu Str., Rīga, LV-1002, LATVIA \\ \# Corresponding author, inese.cakstina@ rsu.Iv
}

Communicated by Jānis Gardovskis

\begin{abstract}
Breast cancer $(B C)$ is the most common cause of cancer-related deaths among women in Europe and worldwide. Adherent (2D) cell cultures have been the routine in vitro model system employed in preclinical $B C$ research for the last half-century. Over the past decade, new protocols have been developed allowing patient-derived three-dimensional organoid (3D) cell culture development from a range of solid tumours, including BC. These 3D models offer a promise of closer resemblance to the native tumour than the $2 D$ cultures. To test the assumption that an in vitro $3 D$ $B C$ model system provides increased faithfulness to the molecular processes happening in vivo, as compared to $2 D B C$ cultures, post-operational material from three BC patients was used to simultaneously develop $2 D$ and $3 D$ cultures in vitro. When analysed by quantitative polymerase chain reaction (PCR), the gene expression patterns of the cells from $3 D$ cultures resembled the original tissues, while the gene expression patterns of the conventional $2 D$ cultures were more distant.
\end{abstract}

Key words: primary breast cancer, patient-derived cell culture, organoids, 3D culture, qPCR.

\section{INTRODUCTION}

Breast cancer (BC) is the leading cause of cancer-related deaths among women worldwide (Bray et al., 2018). In order to aid in cancer research, employment of the up-to-date best $\mathrm{BC}$ model systems in preclinical settings is paramount. Adherent, referred to as $2 \mathrm{D}$, cell cultures have been the most common in vitro model system employed in cancer research for decades (Sachs and Clevers, 2014). New protocols have been established over the past decade that now allow patient-derived three-dimensional (3D) culture development from a range of tumours such as colorectal, prostate, pancreatic, liver, oesophageal, bladder, lung, gastric, kidney, ovarian and breast (Blejs et al., 2019). The consensus is that these 3D cultures largely recapitulate the intra- and inter-tumour heterogeneity of the parental tumours (Sachs and Clevers, 2014). Interestingly, there are only a few studies in which primary tumour cells have been cultivated side by side as 2D and 3D cultures. Furthermore, they have employed commercially available cell lines rather than attempted establishing cultures from patient-derived cancerous tissue (Azadi et al., 2020; Muguruma et al., 2020). Nevertheless, it is not uncommon to see publications with a declaration that 3D culture methods reproduce the organism environment better than 2D culture, followed by references to other research papers that have not even employed parallel cell culture methods (Muguruma et al. 2020). In this pilot study, 2D (adherent) and 3D cell cultures (method from Sachs et al., 2018) from patient-derived tumour primary cells were simultaneously established. We were able to demonstrate that the gene expression patterns of 3D cultures resemble those of the original tissue, while those of the conventional $2 \mathrm{D}$ cultures were more distant.

\section{MATERIALS AND METHODS}

Two post-surgery breast cancer tissue samples - the cancerous core (CA) and the resection line of removed breast tissue (RL) - were obtained from three female patients undergoing unilateral BC surgery at Pauls Stradin̄̌ Clinical University Hospital. All patients were over 75 years old $(95$, 76 , and 80 years old). The first and the second patient had invasive ductal carcinoma, luminal A molecular subtype, while the third patient had invasive lobular carcinoma, luminal B molecular subtype. None of the patients had previ- 
ously received neoadjuvant therapy. The study was approved by the Central Medical Ethics Committee Protocol Nr. 2019-3, point 10. Written patient informed consents for research use of their tissue in this study were obtained prior to the surgery and sample acquisition.

2D cultures were maintained as described by Pirsko et al. (2019). The collected cells were subsequently subcultured into DMEM/ F12, 10\% FBS (A10) or HuMEC basal serum-free medium (Thermo Fisher Scientific) supplemented with HuMEC supplement (GIBCO), Pituitary extract bovine (Sigma-Aldrich), and Primocin (InvivoGen) to promote growth of human mammary epithelial cells (HuMEC medium). HuMEC medium is specifically engineered to culture human mammary epithelial cells. It is also a medium that supposedly should prevent fibroblast overgrowth and thus culture contamination (Mather and Roberts, 1998). Cell cultures were maintained for five passages. Total RNA was extracted from lysates of the earliest available passage of each culture by TRI Reagent (Sigma-Aldrich) according to the manufacturer's protocol. The quantity and quality of the extracted RNA was assessed by NanoDrop 1000 spectrophotometer (Thermo Fisher Scientific) and 1.8\% agarose gel electrophoresis directly after extraction, as well as after polymerase chain reaction (PCR) with primers amplifying reference genes in order to examine its contamination with genomic DNA; PCR for the positive and the negative control were performed alongside. When deemed necessary, RNA samples underwent treatment with DNase I (Sigma-Aldrich) and purification by NucleoSpin RNA XS (Macherey-Nagel); $1 \mu \mathrm{g}$ purified RNA was used to synthesise cDNA by High Capacity cDNA Reverse transcription kit (Thermo Fisher Scientific) according to the manufacturer's protocol. The quality of the synthesised cDNA was assessed by PCR with primers amplifying reference genes, followed by $1.8 \%$ agarose gel electrophoresis.

Real-time qPCR was performed using $5 \mathrm{ng}$ of cDNA per reaction as the template, HOT FIREPol EvaGreen qPCR Supermix (Solis Biodine) and a primer pair on qPCR system ViiA7 (Thermo Fisher Scientific). Three technical rep-

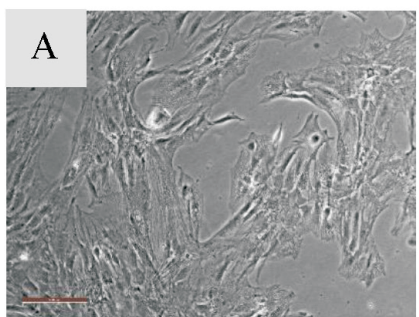

CA03 in A10

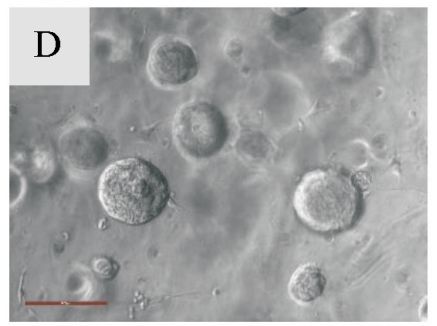

$\mathrm{CA} 02$ in $\mathrm{BC}$ medium
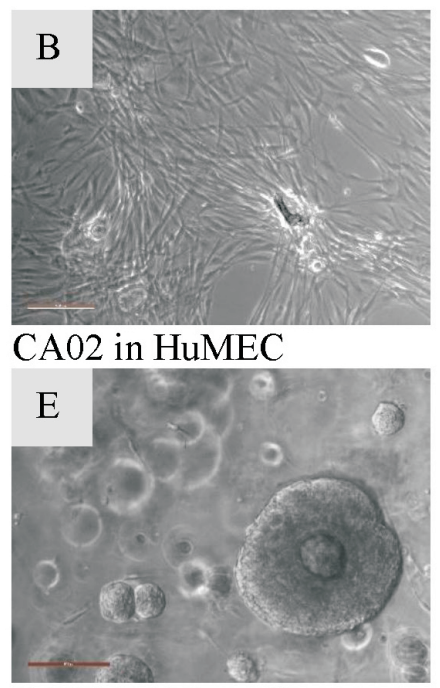

$\mathrm{CA} 02$ in $\mathrm{BC}$ medium

licates were performed for each sample with each primer pair. The qPCR conditions were a single cycle of $95^{\circ} \mathrm{C}$ for 4 min and 40 cycles of denaturation at $95^{\circ} \mathrm{C}$ for $15 \mathrm{~s}$, annealing at $58^{\circ} \mathrm{C}$ for $30 \mathrm{~s}$, and elongation at $72{ }^{\circ} \mathrm{C}$ for $30 \mathrm{~s}$, followed by a high-resolution melting curve, which was employed as the qPCR quality control.

The choice of the reference genes (HSPCB and RNA28S) was based on the results by RefFinder, which is a webbased tool that uses NormFinder, geNorm, BestKeeper and Comparative $\Delta \mathrm{Ct}$ to rank and compare candidate reference genes. It required an additional qPCR plate designated for all the samples of interest and 12 references genes available to us.

3D culture establishment, maintenance and passaging were performed according to Sachs et al. (2018). During passaging, the material was resuspended in cold BME and reseeded at ratio 1:3. Cell cultures were maintained for up to five passages.

\section{RESULTS}

Five of six tissue samples from three patients undergoing breast cancer surgery yielded 3D cell lines, which was in line with the high success rate of 3D culture establishment, exceeding 80\%, reported previously (Sachs and Clevers, 2014; Boj et al., 2015; Sachs et al., 2018). The fact the 3D cultures can be readily established from a small amount of tissue obtained by core biopsies gives promise to personalised approaches for breast cancer patients.

In line with the observation by Sachs et al. (2018), cells from ductal $\mathrm{BC}$ yielded almost exclusively cohesive organoids (solid or cystic), while dis-cohesive (grape-like) organoids were chiefly present in the culture derived from the patient with lobular carcinoma (Fig. 1 F). In 2D cultures, the phenotype resembling fibroblasts was the most prevalent both in CA and RL cell cultures, regardless of the employed growth medium (A10 or HuMEC), possibly indicating culture contamination with stromal cells hijacking
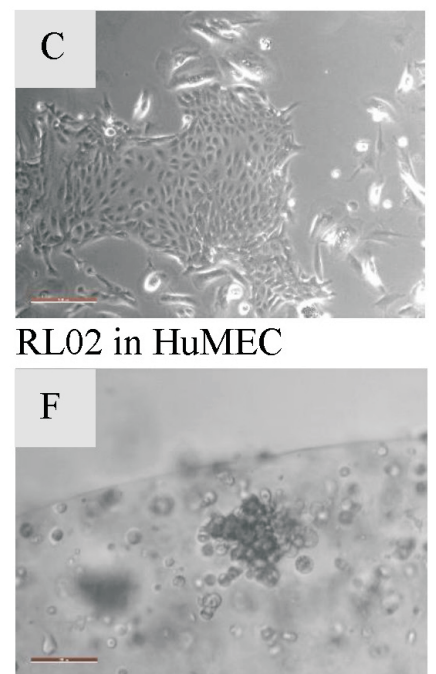

CA03 in BC medium
Fig. 1. Diversity of morphologies of the established cultures. The top row shows $2 \mathrm{D}$ cultures and the scale bar corresponds to $200 \mu \mathrm{m}$, while the bottom row - 3D cultures with scale bar of 100 $\mu \mathrm{m}$. 
acquisition of BC cell lines. In HuMEC medium, we also observed brick-like cell growth typical of epithelial cells in adhesive cell cultures.

Cells were cultured approximately for one month (median 36 (IQR 26-41) days) before the first sample for total RNA extraction could be acquired from a culture. The median cultivation time until the first sample acquisition did not differ significantly among different growth media (KruskalWallis $\mathrm{H}=2.9612, \mathrm{p}=0.2275$ ).

Finally, we compared the expression levels of genes related with different signalling pathways and embryonic stem cell makers in the cultured cells (both 2D and 3D) with those of the original tissues (Fig. 2).

3D culture yielded cells with gene expression patterns similar to the original breast tissues, while $2 \mathrm{D}$ cultures formed a separate cluster in all three patients. All samples displayed relatively a high expression of the gene CTNNB1 coding for $\beta$-catenin, which is a component of the canonical Wnt signalling pathway regulating development and stemness. PYGO2, which products (Pygopus homolog 2) acts as a co-activator of Wnt signalling pathway together with $\beta$-catenin, it was further increased in the original tumour tissues and $3 \mathrm{D}$ cultures, but not in 2D cultures, although the difference was not statistically significant. Original tissue and 3D cultures also showed a higher expression of GATA3 (mature luminal regulator - induces the maturation of precursor cells into breast epithelial cells and maintains these cells in their mature state in mice and possibly humans), CDH1 (encoding epithelial cadherin which is necessary for cell adhesion) than $2 \mathrm{D}$ cells. On the other hand, the original tissue and 3D cultures showed lower expression of SNAII and SNAI2 (both involved in migration and invasion). All samples had low expression of tumour suppressor gene AXIN2 and stemness markers NANOG and NODAL.

Most of the total variance in gene expression could be explained by the first two principal components (PC1 and PC2) in all three sets of samples derived from different patients. Overall, we could see variation among the three sets of samples in the main contributing genes to their gene expression patterns. The common genes, which had great contribution to the gene expression variance, among all three sets of samples were PYGO2, GATA3, CDH1, SNAI1, SNAI2, and NANOG.

\section{DISCUSSION}

The drawback of $3 \mathrm{D}$ cultures compared to $2 \mathrm{D}$ cultures is their more cumbersome maintenance, necessity to use a more complex growth medium and possible requirement of embedment in extracellular matrix (Sachs and Clevers, 2014). Extracellular matrix is the defining characteristic of the type of 3D culture system. This can be omitted (scaffold-free cultures, also called 3D spheroids or microtissues) and an alternative option is an artificial extracellular matrix (including synthetic polymers, self-assembling peptides, or naturally derived materials such as silk, cellulose, or alginate), or a natural extracellular matrix (purified from animals, is highly complex and contains a variety of solubilised basement membrane proteins, principally, collagen IV, laminin, hyaluronic acid; most similar to the in vivo environment) (Astashkina et al., 2012).

The first basic protocol for BC 3D culture development was released by DeRose et al. in 2013. A new efficient protocol for the culture of primary BC organoids was suggested by Sachs et al. (2018). They employed embedment in natural (mural chondrosarcoma-derived) extracellular matrix and presented the growth medium with an increased number of growth and niche factors, including the mitogen Neuregulin 1 , which allowed for long-term expansion of BC 3D cultures and eventually establishment of a living $\mathrm{BC}$ organoid biobank. Their study also showed that 3D cultures could be a promising in vitro model system to guide individualised BC therapy.

One of the advantages of this study is that the 2D and 3D cultures were obtained and maintained side by side. The hierarchical clustering heatmaps for each patient material showed that $3 \mathrm{D}$ cultures appeared conclusively superior to the $2 \mathrm{D}$ cultures at recapitulating the transcriptomic characteristics of the original tissues (Fig. 2). One of the puzzling observations, however, was that the employed BC model system (2D or 3D) had a greater impact on sample clustering by their gene expression pattern, than effect of the origin of the sample from each patient (RL or CA). The tissue and the 3D cultures formed a common cluster, disregarding their origin from the RL or the CA. Sachs et al. (2018) showed that $3 \mathrm{D}$ cultures retain the genetic heterogeneity of the original $\mathrm{BC}$ tissues and it that possibly subtle differences in gene expression ranges of subpopulations are not apparent at the overall population level. Each 2D culture, on the other hand, has undergone selection for a fraction of the entire population that is more adapted to the growth environment and is therefore comparatively homogenous, but does not necessarily capture the mean gene expression level of its original cell population (Lacroix and Leclercq, 2004). Undoubtedly, the gene panel of only 11 selected genes (mostly related to signalling pathways), which was used for screening purposes, was small and could account for the suboptimal sensitivity to distinguish between the two origins. Moreover, Goldhammer et al. (2019) highlighted the inherent difficulties to obtain $\mathrm{BC}$ biopsies free of non-malignant cells. In fact, the authors observed that to some extent (generally, small) non-malignant organoids were present in all primary human BC-derived 3D cultures (Goldhammer et al., 2019).

Interestingly, even though in adherent cultures maintained in HuMEC medium we also observed brick-like cell growth typical of epithelial cells, the ability of HuMEC medium to improve recapitulation of transcriptomic characteristics of the original breast tissue (as compared to cultivation in A10) was not apparent, even though the small number of studied samples from HuMEC medium, as well as the employed limited gene panel size, restricted us from drawing 


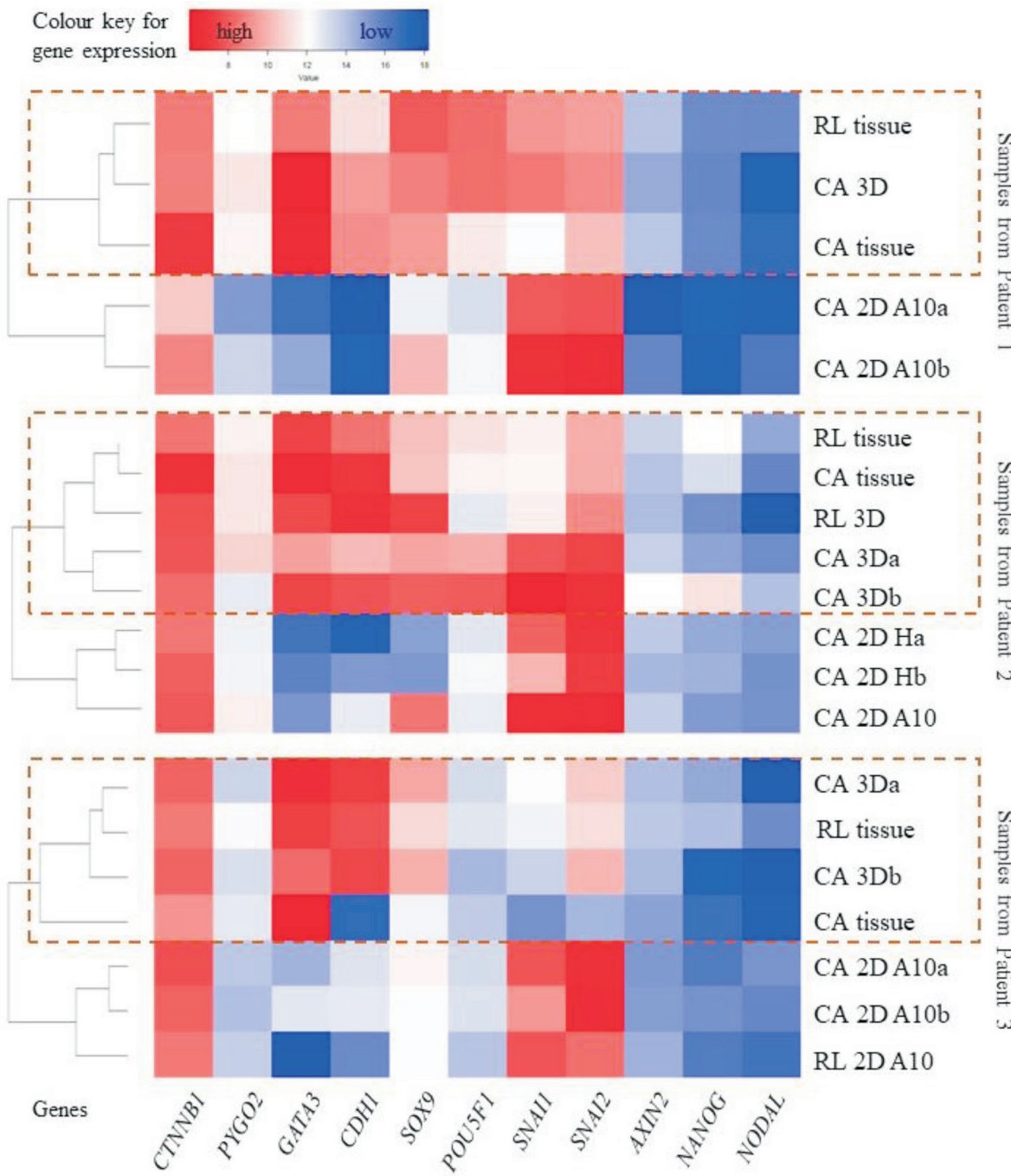

Fig. 2. Heatmaps for cultures derived from patient 1 (top), 2 (middle), and 3 (bottom). Samples are organised in rows and genes - in columns. The gene expression is marked by colour intensity - highly expressed genes are labelled red, and genes with low expression are labelled blue. The sample name depicts its origin (cancerous core (CA), resection line (RL), original tissue, 3D or 2D culture) and for 2D cultures - also the growth medium: A10 or HuMEC $(\mathrm{H})$. When two biological replicates were analysed, they were named identically followed by a or b. any strong conclusions about the superior $2 \mathrm{D}$ culture in regard to gene expression faithfulness to the original tissue.

Based on principal component analysis, the common genes in all three data sets driving the gene expression variance were PYGO2, GATA3, CDH1, SNAI1, SNAI2, and NANOG. Firstly, the observed upregulation of the Wnt signalling pathway in our samples was not surprising as it has previously been linked to several cancer types, including BC (Ramakrishnan and Cadigan, 2017; van Schie and van Amergongen, 2020). The expression of the markers of stemness (NANOG (and also NODAL)) was overall relatively low in tissues and cultures alike, most likely demonstrating the smaller population of cells manifesting stemcell like properties. The expression pattern of the other genes overall support the assumption that the in vitro $3 \mathrm{D}$ $\mathrm{BC}$ model system provides an increased faithfulness to the in vivo environment, in which also the migration of cells is sterically hindered but adhesions are distributed in all three dimensions; cells in 2D cultures, however, are unconstrained to spread and migrate on the surface of the growth container (in line with relatively increased SNAII and SNAI2 expression), but adhesions are restricted (in line with relatively decreased expression of epithelial cadherinencoding CDH1) (Baker and Chen, 2012). Clearly, further analysis of the protein profile of our samples could infer the cell biological alterations in different microenvironments.

\section{CONCLUSION}

In this pilot study we explored the possibility of cell expansion in 3D and in 2D culture simultaneously from likely normal mammary epithelium (tissue from RL) and primary $\mathrm{BC}$ (CA). The gene expression signatures of patient derived $3 \mathrm{D}$ cultures resembled those of the original tissue better than those of $2 \mathrm{D}$ cultures that were cultivated side by side. Implementation of 3D cultures is clearly interesting for $\mathrm{BC}$ research alone. Nevertheless, we can see how the use of 3D cultures could fit in in the early BC organisation of care (Cardoso et al., 2019), principally through drug screening to increase the likelihood of satisfactory drug response in systemic induction therapy and enabling the option to proceed with breast-conserving surgery.

\section{ACKNOWLEDGEMENTS}

We thank all the patients participating in this study as well as the medical staff approaching patients for consent and 
assisting in collecting the tissue. The present study was funded by Rīga Stradiňš University (RSU) Project Nr. 5-1/127/2019.

\section{REFERENCES}

Astashkina, A., Mann, B., Grainger, D. W. (2012). A critical evaluation of in vitro cell culture models for high-throughput drug screening and toxicity. Pharmacol. Ther., 134, 82-106.

Azadi, M., Jamali, T., Kianmehr, Z., Kavoosi, G., Ardestani, S. K. (2020). In-vitro (2D and $3 \mathrm{D}$ cultures) and in-vivo cytotoxic properties of Zataria multiflora essential oil (ZEO) emulsion in breast and cervical cancer cells along with the investigation of immunomodulatory potential. $J$. Ethnopharmacol., 257, 112865.

Baker, B. M., Chen, C. S. (2012). Deconstructing the third dimension - how 3D culture microenvironments alter cellular cues. J. Cell. Sci., 125 (Pt 13), 3015-3024.

Bray, F., Ferlay, J., Soerjomataram, I., Siegel, R. L., Torre, L. A., Jemal, A. (2018). Global Cancer Statistics 2018: GLOBOCAN estimates of incidence and mortality worldwide for 36 cancers in 185 countries. CA Cancer J. Clin., 68 (6), 394-424.

Bleijs, M., van de Wetering, M., Clevers, H., Drost, J. (2019). Xenograft and organoid model systems in cancer research. EMBO J., 38 (15), e101654.

Boj, S. F., Hwang, C.-I., Baker, L. A., Chio, I. I. C., Engle, D. D., Corbo, V., Jager, M., Ponz-Sarvise, M., Tiriac, H., Spector, M. S. et al. (2015). Organoid models of human and mouse ductal pancreatic cancer. Cell, 160 (1-2), 324-338.

Cardoso, F., Kyriakides, S., Ohno, S., Penault-Llorca, F., Poortmans, P., Rubio I. T., Zackrisson, S., Senkus, E. (2019). Early breast cancer: ESMO
Clinical Practice Guidelines for diagnosis, treatment and follow-up. Ann. Oncol., 30 (8), 1194-1220.

DeRose, Y. S., Gligorich, K. M., Wang, G., Georgelas, A., Bowman, P., Courdy, S. J., Welm, A. L., Welm, B. E. (2013). Patient-derived models of human breast cancer: Protocols for in vitro and in vivo applications in tumor biology and translational medicine. Curr. Protoc. Pharmacol, Chapt. 14, Unit14.23.

Goldhammer, N., Kim, J., Timmermans-Wielenga, V., Petersen, O. W. (2019). Characterization of organoid cultured human breast cancer. Breast Cancer Res., 21, 141.

Muguruma, M., Teraoka, S., Miyahara, K., Ueda, A., Asaoka, M., Okazaki, M., Kawate, T., Kuroda, M., Miyagi, Y., Ishikawa, T. (2020) Differences in drug sensitivity between two-dimensional and three-dimensional culture systems in triple-negative breast cancer cell lines. Biochem. Biophys. Res. Commun., 533 (3), 268-274.

Pirsko, V., Čakstina, I., Nitiša, D., Samoviča, M., Daneberga, Z., Miklaševičs, E. (2019). Alterations of the stem-like properties in the breast cancer cell line MDA-MB-231 induced by single pulsed doxorubicin treatment. Proc. Latvian Acad. Sci., Section B, 73 (2), 89-99.

Ramakrishnan, A.-B., Cadigan, K. M. (2017). Wnt target genes and where to find them. F1000Research, 6 (F1000 Faculty Rev), 746.

Sachs, N., Clevers, H. (2014). Organoid cultures for the analysis of cancer phenotypes. Curr. Opin. in Genet. Dev., 24, 68-73.

Sachs, N., de Ligt, J., Kopper, O., Gogola, E., Bounova, G., Weeber, F., Balgobind, A. V., Wind, K., Gracanin, A., Begthel, H. et al. (2018). A living biobank of breast cancer organoids captures disease heterogeneity. Cell, 172, 373-386.

van Schie, E. H., van Amergongen, R. (2020) Aberrant WNT/ CTNNB1 signaling as a therapeutic target in human breast cancer: Weighing the evidence. Front. Cell Dev. Biol., 31, 25.

\section{PRIMĀRO KRŪTS AUDZĒJU TRANSKRIPTOMISKO IEZİMJU REKAPITULĀCIJA NO PACIENTA MATERIĀLA IEGŪTĀS IN VITRO 3D KULTŪRĀS}

Krūts audzējs ir visbiežākais ar audzējiem saistītās nāves cēlonis sievietēm ne tikai Eiropā, bet arī visā pasaulē. Pēdējā pusgadsimta pirmsklīniskie pētījumi lielākoties veikti, izmantojot adherento (2D) šūnu kultūru in vitro modeḷsistēmas, tomēr pēdējos gados radīti jauni šūnu kultivēšanas protokoli, ḷaujot iegūt trīsdimensiju (3D) kultūras no dažādiem, t.sk., krūts, l̦aundabīgiem audzējiem, kas strukturāli līdzinās oriǵinālajam audzējam vairāk nekā 2D kultūras. Lai pārbaudītu hipotēzi, ka 3D šūnu kultūras ir labāk piemērotas in vivo notiekošo molekulāro procesu analīzei nekā 2D kultūras, no trīs krūts vēža pacientu pēcoperācijas materiāla vienlaikus tika iegūtas 2D un 3D in vitro šūnu kultūras, kas vēlāk tika analizētas, izmantojot polimerāzes k̦ēdes reakciju. Pētījuma gaitā demonstrējām, ka 3D šūnu kultūru transkriptomiskās iezīmes līdzinās oriǵinālajiem audiem labāk nekā 2D šūnu kultūru transkriptomiskās iezīmes. 